\title{
Methane Emission of Cattle Fed Urochloa brizantha Hay Harvested at Different Stages
}

\author{
C. F. M. Nascimento ${ }^{1}$, A. Berndt ${ }^{2}$, L. A. Romero ${ }^{1}$, P. M. Meyer ${ }^{3}$, R. T. S. Frighetto ${ }^{4}$, J. J. A. A. Demarchi ${ }^{5}$ \\ \& P. H. M. Rodrigues ${ }^{1}$ \\ ${ }^{1}$ Departamento de Nutrição e Produção Animal, Universidade de São Paulo (FMVZ-USP), Pirassununga, São \\ Paulo, Brazil \\ ${ }^{2}$ Embrapa Pecuária Sudeste, São Carlos, São Paulo, Brazil \\ ${ }^{3}$ Instituto Brasileiro de Geografia e Estatística (IBGE), Pirassununga, São Paulo, Brazil \\ ${ }^{4}$ Embrapa Meio Ambiente, Jaguariúna, São Paulo, Brasil \\ ${ }^{5}$ Instituto de Zootecnia, Nova Odessa, São Paulo, Brazil \\ Correspondence: A. Berndt, Embrapa Pecuária Sudeste, São Carlos, São Paulo 13560-970, Brazil. Tel: \\ 55-16-3411-5629. Fax: 55-16-3361-5754. Email: alexandre.berndt@embrapa.br
}

Received: October 10, 2015 Accepted: November 22, 2015 Online Published: December 15, 2015

doi:10.5539/jas.v8n1p163 URL: http://dx.doi.org/10.5539/jas.v8n1p163

\begin{abstract}
The objective of this trial was to assess the methane emission rate, as well as the digestibility and ruminal fermentation parameters in animals fed Urochloa brizantha hay harvested at different stages of growth. Six Nellore rumen-cannulated steers $(402.0 \pm 51.62 \mathrm{~kg})$ were assigned to a replicated $3 \times 3$ Latin square $(18$ experimental units). Treatments differed according to three growth stages of the forage: 15 - hay with 15 days of growth, 45 - hay with 45 days of growth and 90 - hay with 90 days of growth. Each experimental period lasted 21 days. From the $8^{\text {th }}$ day, feces were sampled during 5 days to determine apparent total digestibility of dry matter and its fractions. Beginning on the $13^{\text {th }}$ day and running for 7 days, methane production was evaluated using the sulfur hexafluoride $\left(\mathrm{SF}_{6}\right)$ tracer technique. On the $20^{\text {th }}$ day, ruminal fluid was sampled prior to and after 2, 4, 6, 8 and 10 hours post-morning feeding for evaluating $\mathrm{pH}$, ammonia-N and short-chain fatty acids (SCFA). As the stage of forage growth for harvesting advanced in days, the digestibility coefficient of crude protein decreased and non-fibrous carbohydrate values increased. Methane production was affected not only by the stage of forage growth, but also by quality of its conservation after harvesting. There were significant differences among treatments when methane was expressed in $\mathrm{g} \mathrm{kg}^{-1} \mathrm{DMI}, \mathrm{g} \mathrm{kg}^{-1} \mathrm{OMI} \%$ GE and \% DE, with non-linear effect. The stage of forage growth did not influence ruminal $\mathrm{pH}$, total concentration or molar proportion of SCFA, but decreased $\mathrm{NH}_{3}-\mathrm{N}$ concentration.
\end{abstract}

Keywords: bovine, enteric methane, metabolic cage, short-chain fatty acids, sulfur hexafluoride, tracer technique

\section{Introduction}

Increasing atmospheric concentrations of greenhouse gases have led to changes in the balance of incoming and outgoing solar radiation and triggered terrestrial warming. In addition to the gases carbon dioxide $\left(\mathrm{CO}_{2}\right)$, nitrous oxide $\left(\mathrm{N}_{2} \mathrm{O}\right)$, chlorofluorocarbons $(\mathrm{CFCs})$ and ozone $\left(\mathrm{O}_{3}\right)$, the methane $\left(\mathrm{CH}_{4}\right)$ is an important greenhouse gas (Cotton \& Pielke, 1995). Global Climate Change has been heavily debated by IPCC (Intergovernmental Panel on Climate Change), and the quantification of greenhouse gases emissions by agricultural ecosystems and the preliminary estimates of these emissions for Brazil showed that livestock is a major source of methane from animal husbandry activities (IPCC, 1995).

The methane produced by ruminal fermentation represents a loss in the potential of energy production, and this issue has been studied for decades (Howden \& Reyenga, 1999). In ruminants, the quantification of gases produced by the rumen has been used as an indicator of ruminal microbial activity, and the methane eructed by the animals represents an energy waste of approximately 2 to $12 \%$ of gross energy intake, which has also led to global warming (K. A. Johnson \& D. E. Johnson, 1995). 
The knowledge of the factors that determine the ruminal fermentation efficiency and the emission of greenhouse gases are essential for reducing the environmental impact caused by animal production systems and for searching increased productivity and economic efficiency of these systems. In Brazil, most production systems are characterized by grazing or using ensiled fodder. This emphasizes the importance of providing good quality roughage with a low proportion of cell wall and high digestibility. In addition, forage management, i.e. the harvest at different stages of maturity and the storage for different periods, is a factor that affects not only the productive efficiency, but also the energy lost by the animal as enteric methane. Thus, the scientific hypothesis proposed for this study was that 1) The methane production rate would be higher and 2) Both dry matter intake and total apparent digestibility would be lower in cattle fed hay harvested at more advanced stages of maturity compared to younger stages. Further, the aims were also to evaluate the methane emission rate using the sulfur hexafluoride $\left(\mathrm{SF}_{6}\right)$ tracer technique for determining nutritional aspects that may be involved in its production and/or mitigation and to assess ruminal fermentation parameters in animals fed Urochloa brizantha hay harvested at different growth stages.

\section{Material and methods}

\subsection{Study Location}

The trial was conducted at the Research and Development Unit - Andradina (Unidade de Pesquisa e Desenvolvimento de Andradina do PRDTA do Extremo Oeste) of Sao Paulo Agency for Agribusiness Technology (APTA - Agência Paulista de Tecnologia dos Agronegócios), State of Sao Paulo, Brazil.

\subsection{Animals, Housing and Feeding}

Six Nellore rumen-cannulated steers were used, weighing $402.0 \pm 51.62 \mathrm{~kg}$, on average. The animals were housed in metabolic cages fitted in stalls with individual feeders and drinkers and assigned to one of three experimental treatments which differed according to the growth stages of the forage harvested for hay: $15-U$. brizantha hay with 15 days of growth, $45-U$. brizantha hay with 45 days of growth and $90-U$. brizantha hay with 90 days of growth. The experimental design was a replicated $3 \times 3$ Latin square representing 18 experimental units referring to 3 animals, 3 periods and 2 squares.

The animals had free access to water and mineral supplement and were supplied with hay twice daily at 08:00 and 16:00 hours. The mineral supplement composition (per kilo of DM) was: $100 \mathrm{~g}$ calcium, $150 \mathrm{mg}$ cobalt, 1,440 mg copper, $12 \mathrm{~g}$ sulfur, $650 \mathrm{mg}$ fluorine (max.), $65 \mathrm{~g}$ phosphorus, $95 \mathrm{mg}$ iodine, $13 \mathrm{~g}$ magnesium, 1,530 $\mathrm{mg}$ manganese, $20 \mathrm{mg}$ selenium, $188 \mathrm{~g}$ sodium and 5,400 $\mathrm{mg}$ zinc.

Hay was produced at the Research and Development Unit - Colina (Unidade de Pesquisa e Desenvolvimento de Colina - PRDTA da Alta Mogiana, State of Sao Paulo, Brazil). The forage was harvested using a mower during the mornings at 15, 45 and 90 days of growth. The soil had not been fertilized. For drying, forage was revolved using a rake during the afternoon in the same day of harvest and then twice in the next day. On the $3^{\text {rd }}$ day, the dried forage was gathered into bales using a mechanical baler. Bales were stored on wooden pallets for one week in a ventilated shed and then transported to the experimental center after a week where they were used in this trial after 5 months of storage. Hay was chopped into $10-\mathrm{cm}$ size particles in order to reduce the selectivity by the animals. The chemical composition of the hay is described in Table 1.

Table 1. Chemical composition of $U$. brizantha hay, expressed in dry matter basis (\% DM)

\begin{tabular}{llll}
\hline \multirow{2}{*}{ Composition $^{1}$} & \multicolumn{3}{c}{ Days of growth of U. brizantha } \\
\cline { 2 - 4 } & 15 & 45 & 90 \\
\hline DM (\%) & 82.52 & 90.17 & 90.04 \\
CP (\%DM) & 10.71 & 4.24 & 4.54 \\
EE (\%DM) & 1.08 & 0.82 & 0.99 \\
Ash (\%DM) & 8.24 & 6.77 & 6.80 \\
NFC (\%DM) & 9.34 & 10.51 & 11.67 \\
NDF (\%DM) & 70.63 & 77.67 & 76.00 \\
ADF (\%DM) & 41.01 & 43.94 & 42.64 \\
ADL (\%DM) & 8.01 & 8.39 & 8.30 \\
\hline
\end{tabular}

Note. ${ }^{1} \mathrm{DM}=$ dry matter, $\mathrm{CP}=$ crude protein, $\mathrm{EE}=$ ether extract, $\mathrm{NFC}=$ non-fiber carbohydrate, $\mathrm{NDF}=$ neutral detergent fiber, $\mathrm{ADF}=$ acid detergent fiber, $\mathrm{ADL}=$ acid detergent lignin. 


\subsection{Sampling Schedule}

The trial consisted of three experimental periods, each lasted 21 days. The first 7 days of the period were used for diet adaptation. The next $8^{\text {th }}$ through $12^{\text {th }}$ days were used for digestibility data collection, and the $13^{\text {th }}$ to $19^{\text {th }}$ days were used for methane collection. On the $20^{\text {th }}$ day, fermentation parameters $\left(\mathrm{pH}, \mathrm{SCFA}\right.$ and $\left.\mathrm{NH}_{3}-\mathrm{N}\right)$ were collected, and on the $21^{\text {st }}$ day the animals were released for exercise. The animals were weighed on the first and last day of each experimental period.

\subsection{Dry Matter Intake Data}

Dry matter intake (DMI) was measured daily from the $8^{\text {th }}$ to $19^{\text {th }}$ day of each experimental period, and the difference between the amount of daily feed supplied and the orts collected was weighed the following morning. This was multiplied by dry matter (DM) content of feed. To ensure ad libitum supply, daily adjustments were made according to the intake so that there were at least $5 \%$ of orts. Intake obtained from the $8^{\text {th }}$ to $12^{\text {th }}$ day was used to calculate digestibility data and intake obtained from the $13^{\text {th }}$ to $19^{\text {th }}$ day was used to express methane emissions.

\subsection{Apparent Total Tract Digestibility}

The in vivo digestibility of diet DM and its fractions (CP, EE, NFC, NDF, ADF and OM) was determined by total collection of feces. From day 8 to 12 , all feces were weighed and a sample $(10 \%)$ was taken directly from collection boxes installed behind the cages. The samples were placed in plastic bags and stored in a freezer at $-20{ }^{\circ} \mathrm{C}$ in order to perform chemical analysis. Different hays used in this trial were also sampled for further analysis.

At the end of the trial, the samples of hay and feces were homogenized and dried in a forced air oven at $65{ }^{\circ} \mathrm{C}$ for $72 \mathrm{~h}$. They were then ground in a mill (using a 1-mm sieve and placed in closed vessels) for subsequent determinations of the following: dry matter content (DM, Method 934.01; AOAC, 1990); ash ( Method 923.03; AOAC, 1990); crude protein (CP, Method 920.87; AOAC, 1990); ether extract (EE), determined gravimetrically after extraction using ether in a Soxhlet extractor (Method 920,85; AOAC, 1990); and neutral detergent fiber (NDF), acid detergent fiber (ADF) and acid detergent lignin (ADL) according to Van Soest (1994). The chemical analyses were performed at the Animal Nutrition and Chemical Analysis Laboratory of Department of Animal Nutrition and Production, College of Veterinary Medicine and Animal Sciences, University of Sao Paulo (Brazil), Pirassununga Campus.

Total digestible nutrients (TDN) of diets were calculated using the formula adapted from Sniffen et al. (1992):

$$
\mathrm{TDN}=(\mathrm{DCP}+\mathrm{DNDF}+\mathrm{DNFC})+(2.25 \times \mathrm{DEE})
$$

Where, DCP is the digestible crude protein, DNDF is the digestible neutral detergent fiber, DNFC is the digestible non-fibrous carbohydrate and DEE is the digestible ether extract.

The non-fibrous carbohydrate (NFC) content of feed was calculated based on nutrient percentages subtracted from $100 \%$ DM, according to NRC (2001):

$$
\mathrm{NFC} \%=100 \%-(\mathrm{CP} \%+\mathrm{NDF} \%+\mathrm{EE} \%+\mathrm{Ash} \%)
$$

\subsection{Enteric Methane Emission}

For determining enteric methane, the sulfur hexafluoride tracer technique was used, as described by K. A. Johnson and D. E. Johnson (1995) and adapted in Brazil by Primavesi et al. (2004).

Prior to the onset of methane collection, sulfur hexafluoride permeation capsules, previously identified, were loaded and calibrated with constant and known release rates of $\mathrm{SF}_{6}$ and were inserted in the rumen. The sampling apparatus consisted of a halter, stainless steel capillary tubing and a collection canister, this latter had an internal pressure near zero atmosphere and was attached to a metal valve and quick-connect coupling for gases. For this technique, a two-stage vacuum pump and a digital manometer were used with a scale from 0 to $203 \mathrm{kPa}$ ( $2 \mathrm{~atm}$ or $29.4 \mathrm{psi}$ or $1,520 \mathrm{~mm} \mathrm{Hg}$; in the range 0 to $2 \mathrm{~atm}$ ). This allowed measurement of the initial and final pressure of each canister during the collection period.

The animals were adapted to the canisters during 5 days prior to collection (from the $8^{\text {th }}$ to $12^{\text {th }}$ day), and then methane production was measured by $\mathrm{SF}_{6}$ tracer technique which was conducted at a 24 hour-intervals over 7 consecutive days, starting from the $13^{\text {th }}$ experimental day. Concentrations of $\mathrm{CH}_{4}$ and $\mathrm{SF}_{6}$ were determined at the laboratory of EMBRAPA Environment, located in Jaguariúna, Sao Paulo State, Brazil, by gas a chromatograph HP6890 (Agilent, Delaware, USA), equipped with flame ionization detector (FID) at $280{ }^{\circ} \mathrm{C}$, column megabore $(0.53 \mathrm{~mm} \times 30 \mathrm{~m} 15 \mu \mathrm{m})$ Plot HP-Al/M (for $\left.\mathrm{CH}_{4}\right)$, electron capture detector $(\mathrm{ECD})$ at $300{ }^{\circ} \mathrm{C}$ and column 
megabore $(0.53 \mathrm{~mm} \times 30 \mathrm{~m} \times 25,0 \mu \mathrm{m}) \mathrm{HP}-\mathrm{MolSiv}$ (for $\mathrm{SF}_{6}$ ), with two loops of $0.5 \mathrm{~cm}^{3}$ maintained at $80{ }^{\circ} \mathrm{C}$ attached to two six-way valves. The gas chromatography column was maintained at $50{ }^{\circ} \mathrm{C}$ during the analysis and heated to $150{ }^{\circ} \mathrm{C}$ for about 15 minutes for cleaning purpose. Soon after the collection period and prior to the determination of $\mathrm{CH}_{4}$ and $\mathrm{SF}_{6}$, the pressurization of the canisters were pressurized to between 1.3-1.5 psi $(\mathrm{g})$ using special nitrogen 5.0, and then readings of the initial and final dilution pressures were taken with a portable digital manometer $( \pm 0.01)$, certified for reading range from -1 to +2 bar $(\mathrm{g})$ (Druck, model DPI705), in order to obtain the dilution factor. Calibration curves were established using standard gases certified by "White Martins" development laboratory, with the concentration for $\mathrm{CH}_{4}$ in ppm $(4.85 \pm 5 \%, 9.96 \pm 1.65 \%$ and $19.1 \pm 3.44 \%)$ and for $\mathrm{SF}_{6}$ in ppt (34.0 $\pm 9.0,91.0 \pm 9.0$ and $\left.978.0 \pm 98.0 \mathrm{ppt}\right)$, according to Westberg et al. (1998).

The methane emission was calculated from the release rate of $\mathrm{SF}_{6}$ and the concentration of $\mathrm{SF}_{6}$ and $\mathrm{CH}_{4}$ in the canisters. The potential emission of methane was then calculated for various values: grams per day $\left(\mathrm{g} \mathrm{d}^{-1}\right)$; grams per hour $\left(\mathrm{g} \mathrm{h}^{-1}\right)$; grams per kilogram of body weight $\left(\mathrm{g} \mathrm{kg}^{-1} \mathrm{BW}\right)$; grams per kilogram of metabolic weight $\left(\mathrm{g} \mathrm{kg}^{-1}\right.$ $\left.\mathrm{BW}^{0.75}\right)$; grams per kilogram of dry matter intake $\left(\mathrm{g} \mathrm{kg}^{-1} \mathrm{DMI}\right)$; grams per kilogram of organic matter intake $(\mathrm{g}$ $\left.\mathrm{kg}^{-1} \mathrm{OMI}\right)$; grams per kilogram of digestible organic matter $\left(\mathrm{g} \mathrm{kg}^{-1} \mathrm{DOM}\right)$; the percentage of gross energy lost as methane ( $\% \mathrm{GE})$, which considered the gross energy intake as calculated from the organic matter intake; and finally, as a percentage of digestible energy lost as methane $(\% \mathrm{DE})$, which also considered the digestible energy intake derived from calculations based on the digestible organic matter.

The conversion of methane from grams to energy unit was performed according to the conversion factor stated by Holter and Young (1992) that methane produces $0.0133 \mathrm{Mcal} \mathrm{g}^{-1}$ when it is burned.

\subsection{Rumen Fermentation Parameters}

For evaluating the ruminal fermentation parameters, ruminal fluid (via cannula) was sampled on the $20^{\text {th }}$ day of each experimental period using a vacuum pump prior to (zero) and 2, 4, 6, 8 and 10 hours of post-morning feeding. A sample of $500 \mathrm{~mL}$ of ruminal fluid was taken each time from five different locations of the rumen. Immediately following the sampling, the $\mathrm{pH}$ was determined using a portable digital $\mathrm{pH}$ meter (HANNA Instruments Limited HI8424, Bedfordshire, UK) that was calibrated with buffer solutions of $\mathrm{pH} 4.0$ and 7.0.

Approximately $5 \mathrm{~mL}$ of ruminal fluid were stored in test tubes and immediately frozen for later assessment of ammonia- $\mathrm{N}\left(\mathrm{NH}_{3}-\mathrm{N}\right)$. This analysis was performed by colorimetry and according to procedures described and adapted by Foldager (1977).

For determining the concentration of SCFA, an aliquot of $100 \mathrm{~mL}$ of ruminal sample was centrifuged at 3,500 rpm for 15 minutes. Then, $1.0 \mathrm{~mL}$ of the supernatant was taken from each vial with a pipette and placed in a test tube (previously prepared with $0.2 \mathrm{~mL}$ of formic acid) and stored at $-20^{\circ} \mathrm{C}$. Subsequently, $1 \mathrm{~mL}$ of was taken of each sample was taken and placed in vials proper for SCFA. They were kept in a controlled-temperature laboratory $\left(25^{\circ} \mathrm{C}\right)$ until the determination of SCFA concentration, which was performed by gas chromatography according to Erwin et al. (1961) that used Finnigan 9001 equipment (Thermo Scientific, West Palm Beach, FL) featuring a glass column of two meters in length and $1 / 8$ " of internal diameter and packed with stationary phase $80 / 120 \%$ Carbopack $^{\circledR}$ B-DA/4\% Carbowax $^{\circledR} 20 \mathrm{M}\left(\right.$ Supelco $\left.^{\circledR}\right)$.

The analyses of ruminal fermentation parameters were done at Chromatography Laboratory of Department of Animal Nutrition and Production, College of Veterinary Medicine and Animal Sciences, University of Sao Paulo (Brazil), Pirassununga Campus.

\subsection{Statistical Analysis}

Data were analyzed using the program Statistical Analysis System (Version 9.2, SAS, 2010) verifying the normality of residuals by the Shapiro-Wilk test. Data that did not fulfill statistical premises underwent either $\operatorname{logarithmic}[\log (\mathrm{x}+1)]$ or square root $[\mathrm{SR}(\mathrm{x}+1 / 2)]$ transformation. Results were analyzed by MIXED procedure of SAS, and the model included the effects of treatments as fixed effects. The effects of the period, the square and the animal nested within the square were considered random effects. Simple polynomial regression was used to evaluate the linear effect and linearity deviation related to growth stages of hay.

Data about ruminal fluid $\mathrm{pH}$ and concentrations of SCFA and $\mathrm{NH}_{3}-\mathrm{N}$ were submitted to an analysis of variance. The repeatedly measured factors (split-plot design) were used for the differing sampling times. Among 15 different covariance structures tested in these analyzes, the one that best fit the statistical model was chosen based on the lower value Corrected Akaike Information Criterion (AICC) (Wang \& Goonewardene, 2004). 


\section{Results}

\subsection{Intake of Dry Matter and Nutrients}

Linearity deviation was found $(\mathrm{P}<0.05)$ for DMI and DDMI, when it was expressed as kilograms per day $(\mathrm{kg}$ $\left.\mathrm{d}^{-1}\right)$ and as a percentage of body weight $(\% \mathrm{BW})$; the highest values were found for hay harvested on the $15^{\text {th }}$ day of growth; the lowest were for hay harvested on the $45^{\text {th }}$ day, and the intermediate values were for hay harvested on $90^{\text {th }}$ day of growth (Table 2). Thus, there was a significant reduction $(\mathrm{P}<0.05)$ in DMI $(28.4 \%$ and $13.2 \%)$ for hay harvested at 45 days of growth compared to the ones harvested at 15 and 90 days of growth, respectively. Regarding DDMI, there was a reduction $(\mathrm{P}<0.05)$ of $31.1 \%$ and $21.1 \%$ for hays harvested at 45 and 90 days compared to the one harvested at 15 days of growth, respectively.

For the intake of CP, EE, NFC, NDF, ADF and lignin, there was linearity deviation $(\mathrm{P}<0.05)$. All these variables had similar pattern regarding their linearity deviation, with the highest intake found for 15 days of forage growth compared to those at 45 days and the intermediate values for hay harvested at 90 days of growth. This fact is directly related to the DMI obtained, which showed the same pattern.

Table 2. Effects of different growth stages of the forage U. brizantha harvested for hay on dry matter and nutrients intake

\begin{tabular}{lllllll}
\hline \multirow{2}{*}{ Variable $^{1}$} & \multicolumn{3}{c}{ Treatments $^{2}$} & \multirow{2}{*}{ SEM $^{3}$} & & \multicolumn{2}{c}{ P value } \\
\cline { 2 - 4 } \cline { 6 - 7 } & 15 & 45 & 90 & & Linear & L. Deviation \\
\hline DMI $\left(\mathrm{kg} \mathrm{d}^{-1}\right)$ & 6.54 & 4.68 & 5.39 & 0.281 & 0.0298 & 0.0024 \\
DMI $(\% \mathrm{BW})$ & 1.63 & 1.19 & 1.37 & 0.064 & 0.0339 & 0.0023 \\
DDMI $\left(\mathrm{kg} \mathrm{d}^{-1}\right)$ & 4.27 & 2.94 & 3.37 & 0.194 & 0.0130 & 0.0024 \\
DDMI $(\% \mathrm{BW})$ & 1.06 & 0.75 & 0.85 & 0.045 & 0.0213 & 0.0042 \\
CPI $\left(\mathrm{kg} \mathrm{d}^{-1}\right)$ & 0.70 & 0.20 & 0.24 & 0.057 & $<0.0001$ & $<0.0001$ \\
EEI $\left(\mathrm{kg} \mathrm{d}^{-1}\right)$ & 0.07 & 0.04 & 0.05 & 0.004 & 0.0011 & $<0.0001$ \\
NFCI $\left(\mathrm{kg} \mathrm{d}^{-1}\right)$ & 0.63 & 0.49 & 0.61 & 0.027 & 0.3498 & 0.0032 \\
NDFI $\left(\mathrm{kg} \mathrm{d}^{-1}\right)$ & 4.62 & 3.64 & 4.10 & 0.186 & 0.1594 & 0.0115 \\
ADFI $\left(\mathrm{kg} \mathrm{d}^{-1}\right)$ & 2.68 & 2.05 & 2.30 & 0.110 & 0.0745 & 0.0087 \\
ADLI $\left(\mathrm{kg} \mathrm{d}^{-1}\right)$ & 0.52 & 0.39 & 0.45 & 0.022 & 0.0692 & 0.0051 \\
\hline
\end{tabular}

Note. ${ }^{1}$ DMI $=$ dry matter intake, DDMI $=$ digestible dry matter intake, $\mathrm{CPI}=$ crude protein intake, $\mathrm{EEI}=$ ether extract intake, NFCI $=$ non-fiber carbohydrate intake, NDFI $=$ neutral detergent fiber intake, ADFI $=$ acid detergent fiber intake, ADLI $=$ acid detergent lignin intake; ${ }^{2} 15=U$. brizantha hay with 15 days of growth, $45=$ $U$. brizantha hay with 45 days of growth, $90=U$. brizantha hay with 90 days of growth; ${ }^{3} \mathrm{SEM}=$ Standard error of mean.

\subsection{Apparent Total Digestibility}

Results regarding the digestibility of dry matter and its fractions, as well TDN (Table 3) are within the expected range, regardless of treatment. 
Table 3. Effects of different growth stages of the forage $U$. brizantha harvested for hay on total apparent digestibility of dry matter and its fractions

\begin{tabular}{lllllll}
\hline \multirow{2}{*}{ Variable $^{1}$} & \multicolumn{3}{c}{ Treatments $^{2}$} & \multirow{2}{*}{ SEM $^{3}$} & & \multicolumn{2}{c}{ P value } \\
\cline { 2 - 3 } \cline { 6 - 7 } & 15 & 45 & 90 & & Linear & L. Deviation \\
\hline DMDC (\%) & 64.23 & 63.12 & 63.03 & 1.705 & 0.6740 & 0.7890 \\
OMDC (\%) & 64.21 & 64.14 & 64.06 & 1.693 & 0.9582 & 0.9972 \\
CPDC (\%) & 64.44 & 40.18 & 41.17 & 3.723 & 0.0007 & 0.0027 \\
EEDC (\%) & 19.74 & 24.86 & 22.81 & 3.596 & 0.7060 & 0.5183 \\
NFCDC (\%) & 35.19 & 47.27 & 50.11 & 2.958 & 0.0174 & 0.1788 \\
NDFDC (\%) & 70.06 & 69.17 & 69.61 & 1.624 & 0.9020 & 0.7804 \\
ADFDC (\%) & 63.79 & 65.58 & 65.83 & 1.948 & 0.5248 & 0.7104 \\
TDN (\%) & 60.16 & 60.53 & 60.97 & 1.584 & 0.7437 & 0.9824 \\
\hline
\end{tabular}

Note. ${ }^{1} \mathrm{DMDC}=$ dry matter digestibility coefficient, $\mathrm{OMDC}=$ organic matter digestibility coefficient, $\mathrm{CPDC}=$ crude protein digestibility coefficient, EEDC $=$ ether extract digestibility coefficient, NFCDC $=$ non-fiber carbohydrate digestibility coefficient, NDFDC $=$ neutral detergent fiber digestibility coefficient, $\mathrm{ADFDC}=$ acid detergent fiber digestibility coefficient, TDN $=$ total digestible nutrients; ${ }^{2} 15=U$. brizantha hay with 15 days of growth, $45=U$. brizantha hay with 45 days of growth, $90=U$. brizantha hay with 90 days of growth; ${ }^{3} \mathrm{SEM}=$ Standard error of mean.

The digestibility coefficients of DM, OM, EE, NDF, ADF, as well TDN, were not affected $(\mathrm{P}>0.05)$ by the treatments. However, linearity deviation $(\mathrm{P}<0.05)$ was found for digestibility coefficient of crude protein, represented by the equation CPDC $(\%)=84.035-1.4726 \mathrm{x}+0.0111 \mathrm{x}^{2}\left(\mathrm{R}^{2}=0.53\right)$.

Positive linear effect $(\mathrm{P}<0.05)$ was observed for the digestibility coefficient of NFC and the equation was NFCDC $(\%)=34.77+0.1882 x\left(R^{2}=0.23\right)$. However, hay harvested at 90 days of forage growth presented the highest digestibility (50.11\%) compared to hays harvested at 15 and 45 days ( 35.19 and $47.27 \%$, respectively). As the fodder $U$. brizantha ripens, the fiber content and lignifications increase, which would lead to lower digestibility of this fraction, a fact that was not observed in this trial. However, true digestibility of NFC is considered to be almost $100 \%$, so increases in apparent digestibility of this fraction were not expected.

\subsection{Methane Emissions}

There was no significant difference $(\mathrm{P}>0.05)$ among treatments for methane values (Table 4) expressed as grams per day $\left(\mathrm{g} \mathrm{d}^{-1}\right)$, grams per hour $\left(\mathrm{g} \mathrm{h}^{-1}\right)$, grams per kilogram of body weight $\left(\mathrm{g} \mathrm{kg}^{-1} \mathrm{BW}\right)$ or grams per kilogram of metabolic weight $\left(\mathrm{g} \mathrm{kg}^{-1} \mathrm{BW}^{0.75}\right)$. Nevertheless, the results of $\mathrm{CH}_{4}$ expressed as grams per kilogram of dry matter intake ( $\left.\mathrm{g} \mathrm{kg}^{-1} \mathrm{DMI}\right)$, grams per kilogram of organic matter intake $\left(\mathrm{g} \mathrm{kg}^{-1} \mathrm{OMI}\right)$, grams per kilogram of digestible organic matter $\left(\mathrm{g} \mathrm{kg}^{-1} \mathrm{DOM}\right)$, percentage of gross energy lost as methane (\% GE) and percentage of digestible energy lost as methane $(\% \mathrm{DE})$ did show the effects of linearity deviation $(\mathrm{P}<0.05)$ because hay harvested at 45 days of forage growth caused higher emission than the other treatments. From these results, the obtained equations for linearity deviation were: $\mathrm{CH}_{4}\left(\mathrm{~g} \mathrm{~kg}^{-1} \mathrm{DMI}\right)=11.87+0.422 \mathrm{x}-0.0037 \mathrm{x}^{2}\left(\mathrm{R}^{2}=0.32\right)$, where $\mathrm{x}=$ growth stage for harvesting forage; $\mathrm{CH}_{4}\left(\mathrm{~g} \mathrm{~kg}^{-1} \mathrm{OMI}\right)=13.42+0.683 \mathrm{x}-0.0060 \mathrm{x}^{2}\left(\mathrm{R}^{2}=0.40\right) ; \mathrm{CH}_{4}$ $\left(\mathrm{g} \mathrm{kg}^{-1} \mathrm{DOM}\right)=19.18+1.354 \mathrm{x}-0.0117 \mathrm{x}^{2}\left(\mathrm{R}^{2}=0.34\right) ; \mathrm{CH}_{4}(\% \mathrm{GE})=3.59+0.199 \mathrm{x}-0.0017 \mathrm{x}^{2}\left(\mathrm{R}^{2}=0.41\right)$ and $\mathrm{CH}_{4}(\% \mathrm{DE})=6.75+0.328 \mathrm{x}-0.0028 \mathrm{x}^{2}\left(\mathrm{R}^{2}=0.34\right)$. 
Table 4. Effects of different growth stages of the forage $U$. brizantha harvested for hay on methane production determined by tracer technique $\mathrm{SF}_{6}$

\begin{tabular}{|c|c|c|c|c|c|c|}
\hline \multirow{2}{*}{ Variable $^{1}$} & \multicolumn{3}{|c|}{ Treatments $^{2}$} & \multirow{2}{*}{$\mathrm{SEM}^{3}$} & \multicolumn{2}{|c|}{ P value } \\
\hline & 15 & 45 & 90 & & Linear & L. Deviation \\
\hline $\mathrm{CH}_{4}\left(\mathrm{~g} \mathrm{~d}^{-1}\right)$ & 132.65 & 138.32 & 133.93 & 7.998 & 0.9658 & 0.6767 \\
\hline $\mathrm{CH}_{4}\left(\mathrm{~g} \mathrm{~h}^{-1}\right)$ & 5.53 & 5.76 & 5.58 & 0.333 & 0.9655 & 0.6778 \\
\hline $\mathrm{CH}_{4}\left(\mathrm{~g} \mathrm{~kg}^{-1} \mathrm{BW}\right)$ & 0.33 & 0.34 & 0.33 & 0.016 & 0.9166 & 0.6395 \\
\hline $\mathrm{CH}_{4}\left(\mathrm{~g} \mathrm{~kg}^{-1} \mathrm{BW}^{0.75}\right)$ & 1.48 & 1.54 & 1.51 & 0.077 & 0.8853 & 0.7043 \\
\hline $\mathrm{CH}_{4}\left(\mathrm{~g} \mathrm{~kg}^{-1} \mathrm{DMI}\right)$ & 17.38 & 23.41 & 20.02 & 1.054 & 0.3812 & 0.0299 \\
\hline $\mathrm{CH}_{4}\left(\mathrm{~g} \mathrm{~kg}^{-1} \mathrm{OMI}\right)$ & 22.32 & 32.03 & 26.39 & 1.531 & 0.3614 & 0.0175 \\
\hline $\mathrm{CH}_{4}\left(\mathrm{~g} \mathrm{~kg}^{-1} \mathrm{DOM}\right)$ & 36.86 & 56.40 & 46.18 & 3.318 & 0.3348 & 0.0340 \\
\hline $\mathrm{CH}_{4}(\% \mathrm{GE})$ & 6.18 & 9.02 & 7.42 & 0.440 & 0.3249 & 0.0168 \\
\hline $\mathrm{CH}_{4}(\% \mathrm{DE})$ & 11.04 & 16.89 & 13.83 & 0.994 & 0.3344 & 0.0340 \\
\hline
\end{tabular}

Note. ${ }^{1} \mathrm{BW}=$ body weight, $\mathrm{DMI}=$ dry matter intake, $\mathrm{OMI}=$ organic matter intake, $\mathrm{DOM}=$ digestible organic matter, $\mathrm{GE}=$ gross energy, $\mathrm{DE}=$ digestible energy; ${ }^{2} 15=U$. brizantha hay with 15 days of growth, $45=U$. brizantha hay with 45 days of growth, $90=U$. brizantha hay with 90 days of growth; ${ }^{3} \mathrm{SEM}=$ Standard error of mean.

\subsection{Ruminal Fermentation Parameters}

There was no interaction $(\mathrm{P}>0.05)$ between sampling time and treatment for any of the rumen fermentation variables (Table 5).

Table 5. Effects of different growth stages of the forage $U$. brizantha harvested for hay on ruminal fermentation

\begin{tabular}{|c|c|c|c|c|c|c|c|}
\hline \multirow{2}{*}{ Variable } & \multicolumn{3}{|c|}{ Treatments $^{1}$} & \multirow{2}{*}{$\mathrm{SEM}^{2}$} & \multicolumn{3}{|c|}{ Pvalue $^{3}$} \\
\hline & 15 & 45 & 90 & & Linear & L. Dev. & Treat*Ti \\
\hline Total SCFA (Mm) & 87.9 & 79.4 & 81.0 & 3.687 & 0.5248 & 0.4988 & 0.6715 \\
\hline Acetic ( $\%$ molar $)$ & 77.0 & 76.5 & 76.3 & 0.385 & 0.0740 & 0.2529 & 0.2306 \\
\hline Propionic ( $\%$ molar) & 17.0 & 17.0 & 16.3 & 0.241 & 0.0767 & 0.2635 & 0.6069 \\
\hline Butiric (\% molar) & 6.01 & 6.49 & 7.40 & 0.269 & 0.0006 & 0.7718 & 0.1489 \\
\hline Ace:Prop ratio & 4.55 & 4.50 & 4.68 & 0.083 & 0.1715 & 0.2595 & 0.6001 \\
\hline $\mathrm{pH}$ & 6.80 & 6.61 & 6.67 & 0.043 & 0.2006 & 0.1119 & 0.6369 \\
\hline $\mathrm{NH}_{3}-\mathrm{N}\left(\mathrm{mg} \mathrm{dL}^{-1}\right)$ & 7.21 & 2.74 & 2.22 & 0.693 & 0.0001 & 0.0013 & 0.1223 \\
\hline
\end{tabular}

Note. ${ }^{1} 15=U$. brizantha hay with 15 days of growth, $45=U$. brizantha hay with 45 days of growth, $90=U$. brizantha hay with 90 days of growth; ${ }^{2} \mathrm{SEM}=$ Standard error of mean; ${ }^{3}$ Linear $=$ Linear effect, L. Dev. $=$ Linearity deviation, Treat* $\mathrm{Ti}=$ Interaction effect between time and treatment.

There was no effect $(\mathrm{P}>0.05)$ from the hay harvested at different stages of growth on molar proportion of acetic and propionic acids or on acetic/propionic ratio. This fact is related to ruminal $\mathrm{pH}$, which was not affected by the treatments either $(\mathrm{P}>0.05)$.

A linear deviation effect was observed $(\mathrm{P}<0.05)$ for ruminal ammonia-N concentration, presented by the equation: $N_{3}-N\left(\mathrm{mg} \mathrm{dL}^{-1}\right)=10.685-0.259 \mathrm{x}+0.0018 \mathrm{x}^{2}\left(\mathrm{R}^{2}=0.59\right)$.

When the $\mathrm{NH}_{3}-\mathrm{N}$ concentration was assessed throughout the sampling times of ruminal fluid (Figure 1), the treatment with hay harvested at 15 days of growth reached peaks of concentration at 2 and 8 hours post-morning feedings. But for treatments with hay harvested at 45 and 90 days, concentrations remained nearly constant with a small increase two hours post-feeding. 


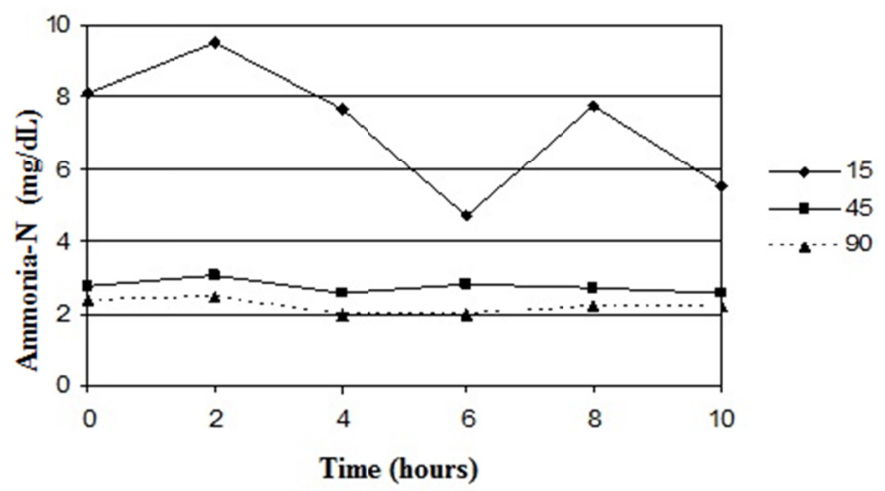

Figure 1. Effects of different growth stages of the forage U. brizantha harvested for hay $(15=\mathrm{U}$. brizantha hay with 15 days of growth, $45=U$. brizantha hay with 45 days of growth, $90=U$. brizantha hay with 90 days of growth) on $\mathrm{NH}_{3}-\mathrm{N}$ concentration $\left(\mathrm{mg} \mathrm{dL}^{-1}\right)$ in ruminal fluid throughout sampling times

\section{Discussion}

\subsection{Intake of Dry Matter and Nutrients}

Higher intakes of dry matter and digestible dry matter are expected for hay harvested at 15 days of growth due to its low content of NDF, ADF and ADL, which characterizes it as a hay of better quality and higher digestibility than the older hays. Likewise, the lower intakes of dry matter and digestible dry matter (expressed as $\mathrm{kg} \mathrm{d}^{-1}$ and as a \% BW) for hays harvested at 45 and 90 days of growth are attributed to a crude protein deficiency, e.g. CP content below $7 \%$, which is a minimum value that would ensure an adequate ruminal microorganism activity (Van Soest, 1994).

Valadares et al. (1997), using diets containing 7.0, 9.5, 12.0 or $14.5 \%$ of CP on a DM basis, observed that $7 \%$ CP diet showed lower dry matter intake than the others. On the other hand, Alves (2001), evaluating DMI of Holstein-Gir, Holstein-Guzerá and Indubrasil breeds during stocker and finishing phases, fed diets with 12 or $15 \%$ of CP and verified that DMI was not influenced by diets. Under similar conditions, Ítavo et al. (2002), who studied finishing steers fed with diets of 15 or $18 \%$ of $\mathrm{CP}$, observed that nutrient intake was not affected by protein content of the diets; only the CP intake was affected.

It is important to emphasize that hay produced at 45 days of forage growth showed poorer quality when compared to the other growth stages tested; the 45 day hay had a yellowish appearance, although it had no indications of fungal growth. This may explain the low results for its dry matter and nutrient intake.

Dry matter intakes, which were expressed as a \% BW of the animals fed with hay harvested at 15, 45 and 90 days of forage growth, were considered low $(1.63,1.19$ and $1.37 \%$, respectively) when compared to the values projected by NRC (1996), which are close to $2.5 \%$ BW for beef cattle. According to Mertens (1997) and Van Soest (1994), in diets with high fiber content or low energy density compared to the animal's requirements conditions observed in this trial by offering exclusively hay - the intake is limited by ruminal fill. Russell et al. (1992) stated that when roughage is degraded very slowly, the ruminal fill may limit intake and consequently the nutritional requirements are not achieved.

The largest quantity of $\mathrm{CP}$ and the lowest quantity of fiber consumed, when fed hay harvested at 15 days of forage growth, was due to its higher nutrient content and its higher dry matter intake as compared to hays harvested at 45 or 90 days of forage growth.

\subsection{Apparent Total Digestibility}

Treatment with hay harvested at 15 days of forage growth showed higher digestibility for CP fraction (64.44\%) compared to hays harvested at 45 and 90 days ( 40.18 and $41.17 \%$, respectively). This effect is related to the chemical composition of the hay harvested at 15 days of forage growth which has higher protein content (10.71\% on DM basis) compared to the other hays. This higher content probably increased proper ruminal microbial activity and led to higher intake of dry matter and protein which thereby increased the digestibility coefficient of CP of the diet. According to Van Soest (1994), the crude protein contents below 7\% (on a DM basis) of some tropical grasses, as observed in this trial for hays harvested at 45 and 90 days of forage growth, promote reduction in the digestion due to inappropriate nitrogen contents for ruminal microorganisms. 


\subsection{Methane Emissions}

The increase in methane emissions when animals were fed hay harvested at 45 days of forage growth can be explained by poorer quality of the latter when compared to the other hays. This was confirmed by intake and digestibility results; moreover, the 45 day hay had a yellowish appearance. Sundstol (1981) stated that the growth stage, conservation method and physical processing of forage affected methane production. Generally, methane production is likely to increase as the growth stage of the forage advances; however, in this trial, the largest methane emission for hay harvested at 45 days of growth was due to the conservation method and to the physical processing of the forage, which led to poor quality hay.

According to Olson et al. (2000), methane emission by beef cattle grazing in native pastures is about $9.9 \mathrm{~g} \mathrm{~h}^{-1}$. This is higher when compared to the average of $5.6 \mathrm{~g} \mathrm{~h}^{-1}$ observed in this trial. The authors found no significant difference in methane emission rates $\left(\mathrm{g} \mathrm{h}^{-1}\right)$ when the quality of the pastures was improved by introducing higher nutritional value forages. They stated that the animals were not able to select good roughage, considering a proper stocking rate for the forage supply.

In trials conducted in metabolic cages using zebu heifers, Kurihara et al. (1999) found that $\mathrm{CH}_{4}$ emissions were 160 and $257 \mathrm{~g} \mathrm{~d}^{-1}$ and 0.42 and $0.71 \mathrm{~g} \mathrm{~kg}^{-1} \mathrm{BW}$ for diets based on concentrate or on temperate forages, respectively. In the same study using poorer quality tropical forage, they observed methane emission of $113 \mathrm{~g} \mathrm{~d}^{-1}$ and $0.32 \mathrm{~g} \mathrm{~kg}^{-1} \mathrm{BW}$. The average methane emission of the present study was $134.97 \mathrm{~g} \mathrm{~d}^{-1}$ and $0.34 \mathrm{~g} \mathrm{~kg}^{-1} \mathrm{BW}$, which is slightly higher than ones found by the above mentioned authors where poor quality tropical forage was used.

For methane emission based on dry matter intake, results between 17.38 and $23.41 \mathrm{~g} \mathrm{~kg}^{-1}$ DMI were found. For hay harvested at 45 days of forage growth, the methane emission was higher $(\mathrm{P}<0.05)$ compared to the other treatments; whereas the hay harvested at 15 days showed the lowest emission. Similar results were found by Possenti et al. (2008), who in trials with two levels of leucaena hay in the diet (20 or $50 \% \mathrm{MS}$ ), observed emissions of 20.49 and $16.90 \mathrm{~g} \mathrm{~kg}^{-1} \mathrm{DMI}$, respectively. In the present trial, the same effect $(\mathrm{P}<0.05)$ was also found for methane emissions expressed as $\mathrm{g} \mathrm{kg}^{-1}$ of organic matter intake; this revealed a similar increase when animals received hay harvested at 45 days of forage growth. The average methane emissions ranged between 36.86 and $56.4 \mathrm{~g} \mathrm{~kg}^{-1} \mathrm{DOM}$, which are in agreement with the range demonstrated by Kurihara et al. (1999), who studied the methane emission of Brahman cattle fed three diets: low quality hay, high quality hay and concentrate diet, with results of $75.4,64.6$ and $32.1 \mathrm{~g} \mathrm{~kg}^{-1} \mathrm{DOM}$, respectively.

The percentage of gross energy lost as methane $(\% \mathrm{GE})$ was higher $(\mathrm{P}<0.05)$ when animals received hay harvested at 45 days $(9.02 \%)$ compared to the other hays harvested at $15(6.18 \%)$ and $90(7.42 \%)$ days of forage growth. In North America and Eastern Europe (USEPA, 2000), the percentage of gross energy lost as methane (\% GE) is estimated ranging between 5.5\% and 6.5\%. However, Kurihara et al. (1999) reported that the energy loss as methane was $10.4 \%$ in animals fed poor quality grass, compared to $6.7 \%$ in concentrate-fed animals. The IPCC (1995) estimated a 7\% loss of gross energy when animals were fed low quality tropical grass and a $6 \%$ loss when received high quality temperate or concentrate diets.

The pattern of the digestible energy lost as methane was similar to the pattern observed for gross energy. It was greater $(\mathrm{P}<0.05)$ for the hay harvested at 45 days of growth $(16.89 \%)$ when compared to the other treatments. Similar to the other $\mathrm{CH}_{4}$ variables obtained, the largest energy loss when animals received this treatment was due to the conservation method of the hay used, which may have limited its energy utilization.

Considering the gross energy lost as methane, the hay harvested at 90 days of forage growth emitted $20.0 \%$ more methane than the hay harvested at 15 days. Given that the response to growth stage would be linear and also hay harvested at 45 days was in good preservation quality, an increase of $8.0 \%$ in methane emission could be expected for hay harvested at 45 days compared to that harvested at 15 days. Instead, the hay harvested at 45 days emitted $46.0 \%$ more methane than the one harvested at 15 days - a difference of 38 percentage units more than the expected. Even considering a non-linear response to the growth stage, the difference still would be high, e.g. 26.0 percentage units more than the expected when hay harvested at 45 days were compared to that harvested at 90 days. Such a difference can only be explained by the poor conservation state of hay harvested at 45 days. It is also important to state that poor conservation quality is not easy to assess by conventional chemical analysis, as no differences were found through chemical analysis between the hays harvested at 45 or 90 days. However, the animals were able to detect this difference in quality and decreased-their intake of the yellowish hay (harvested at 45 days). The results obtained in this study bring new information, especially about the sensitivity (risk of bias) in the prediction models when the objective is to predict enteric methane emission by ruminants based on feed quality data. 


\subsection{Ruminal Fermentation Parameters}

The average results of $\mathrm{pH}$ remained close to the ideal range for optimal fiber digestion and growth of cellulolytic bacteria populations, according to the $\mathrm{pH}$ values (from 6.5 to 6.8) recommended by Orskov (1982).

Moreover, a positive linear effect $(\mathrm{P}<0.05)$ of forage harvesting stages was found for the molar proportion of butiric acid. The hay harvested at 90 days of growth showed higher proportion, followed by hays with 45 and 15 days of growth. Although statistically significant, this effect was numerically small.

Ammonia-N concentrations $\left(\mathrm{mg} \mathrm{dL}^{-1}\right)$ were lower for treatments containing the hays harvested at 45 or 90 days of growth (2.74 and $2.22 \mathrm{mg} \mathrm{dL}^{-1}$, respectively) when compared to the hay harvested at 15 days of growth (7.21 $\mathrm{mg} \mathrm{dL}^{-1}$ ). This is due to the protein content of the hay harvested at 15 days of growth, which resulted in a higher amount of digestibility of crude protein and therefore a larger amount of nitrogen for the rumen. It is important to highlight that $\mathrm{NH}_{3}-\mathrm{N}$ contents directly relate to dietary CP amounts (Freeman et al., 1992; Huntington et al., 1996; Thivierge et al., 2002), a fact observed in this trial. Furthermore, it is worth mentioning that the activity of cellulolytic microorganisms is highly dependent on ruminal $\mathrm{NH}_{3}-\mathrm{N}$ concentration.

According to Satter and Roffler (1979), the minimum concentration should be around $5 \mathrm{mg} \mathrm{dL}^{-1}$ of $\mathrm{NH}_{3}-\mathrm{N}$ in the ruminal fluid so that there would be no limitation to the microbial fermentation; however, the $\mathrm{NH}_{3}-\mathrm{N}$ concentration differs among authors: Satter and Slyter (1974) and Slyter et al. (1979) stated that the optimal concentration to ensure ideal microbial activity is between 2 and $5 \mathrm{mg} \mathrm{dL}{ }^{-1}$ of $\mathrm{NH}_{3}-\mathrm{N}$ in the ruminal fluid. Pedreira (2004) proposed $3.15 \mathrm{mg} \mathrm{dL}^{-1}$ for diets based exclusively on roughage (sorghum silage, $5 \% \mathrm{CP}$ and 35.5 DM) and $6.68 \mathrm{mg} \mathrm{dL}^{-1}$ for diets based on concentrate (60\%). By contrast, Preston \& Leng (1987) suggested that this concentration should be $20 \mathrm{mg} \mathrm{dL}^{-1}$ of $\mathrm{NH}_{3}-\mathrm{N}$. Nevertheless, Morrison \& Mackie (1996) claimed that the optimal ruminal concentration is the one that leads to a more efficient microbial protein synthesis. Thereby, $\mathrm{NH}_{3}-\mathrm{N}$ concentrations observed in the present trial are within the range suggested by some authors. For the hay harvested at 15 days of growth, the concentration can be considered in the normal range for not limiting ruminal fermentation.

Results of this study about the $\mathrm{NH}_{3}-\mathrm{N}$ concentration of the ruminal fluid sampling were similar to those mentioned by Queiroz et al. (2011), who worked with beef cattle fed $U$. brizantha cv. Marandu having 30 or 60 days of regrowth. They found a maximum ammonia-N concentration peak two hours post-feeding due to the high value of fraction A of forage protein which was characterized by the rapid microbial degradation in the rumen. Conversely, Owens and Zinn (1988) suggested that there is variation in the ammonia-N concentration throughout the post-feeding hours and that intensity depends on the type of feed. Therefore, when animals are fed urea, the ammonia-N reaches maximum concentration between 1 and 2 hours post-supplying, while diets rich in forage protein lead to peak between 3 and 4 hours post-consuming.

In this experiment, it was not possible to explain the differences in methane emission using the metabolic pattern of rumen fermentation because it was based only on concentration data (especially acetic and propionic).

\section{Conclusions}

The apparent total tract digestibility of DM and its fractions was not affected by the growth stages of harvesting hay, except for crude protein digestibility. Hay harvested at different stages of forage growth did not influence ruminal fermentation pattern. However, ammonia- $\mathrm{N}$ was influenced by the protein amount of treatments.

Although not detected by the chemical analysis in the laboratory, the qualitative characteristics of the conserved forage, except for the stages of forage growth, affect its nutritional value and can lead to differences in methane emission per unit of dry matter and nutrients ingested.

\section{Acknowledgements}

The authors thank Fundação de Amparo à Pesquisa do Estado de São Paulo (FAPESP) for research funding.

\section{References}

Alves, D. D. (2001). Desempenho produtivo e características de carcaças de bovinos zebu e cruzados Holandês-zebu (F1), nas fases de recria e terminação (Unpublished master's thesis, Universidade Federal de Viçosa, Brasil).

AOAC. (1990). Official Methods of Analysis of the Association of Official Analytical Chemists (15th ed.). Washington, DC: Association of Official Analytical Chemists.

Cotton, W. R., \& Pielke, R. A. (1995). Human impacts on weather and climate. Cambridge University Press: New York. 
Erwin, E. S., Marco G. J., \& Emery, E. M. (1961). Volatile fatty acids analyses of blood and rumen fluid by gas $\begin{array}{lllll}\text { chromatography. Journal of Dairy } & \text { Science, } & 44, & 1768-1771 .\end{array}$ http://dx.doi.org/10.3168/jds.S0022-0302(61)89956-6

Foldager, J. (1977). Protein requirement and non protein nitrogen for high producing cow in early lactation (Unpublished doctoral dissertation, Michigan State University, USA).

Freeman, A. S., Galyean, M. L., \& Caton, J. S. (1992). Effects of supplemental protein percentage and feeding level on intake, ruminal fermentation, and digesta passage in beef steers fed prairie hay. Journal of Animal Science, 70, 1562-1572. http://dx.doi.org//1992.7051562x

Holter, J. B., \& Young, A. J. (1992). Methane prediction in dry and lactating Holstein cows. Journal of Dairy Science, 75, 2165-2175. http://dx.doi.org/10.3168/jds.S0022-0302(92)77976-4

Howden, S. M., \& Reyenga, P. J. (1999). Methane emissions from Australia livestock: Implications of Kyoto Protocol. Australian Journal of Agricultural Research, 50, 1285-1291. http://dx.doi.org.sci-hub.org/10.1071/AR99002

Huntington, G. B., Zetina, E. J., Whitt, J. M., \& Potts, W. (1996). Effects of dietary concentrate level on nutrient absorption, liver metabolism, and urea kinetics of beef steers fed isonitrogenous and isoenergetic diets. Journal of Animal Science, 74, 908-916. http://dx.doi.org//1996.744908x

IPCC (Intergovernmental Panel on Climate Change). (1995). Climate Change 1994: Radiative forcing of climate change and an evaluation of the IPCC IS92 emission scenarios. Cambridge University Press: Cambridge, UK.

Ítavo, L. C. V., Valadares Filho, S. C., Silva, F. F., Valadares, R. F. D., Cecon, P. R., Ítavo, C. C. B. F., ... Paulino, P. V. R. (2002). Níveis de concentrado e proteína bruta na dieta de bovinos Nelore nas fases de recria e terminação: consumo e digestibilidade. Revista Brasileira de Zootecnia, 31(2), 1033-1041. http://dx.doi.org/10.1590/S1516-35982002000400028

Johnson, K. A., \& Johnson, D. E. (1995). Methane emissions from cattle. Journal of Animal Science, 73, 2483-2492. http://dx.doi.org//1995.7382483x

Kurihara, M., Magner, T., Hunter, R. A., \& McCrabb, G. J. (1999). Methane production and energy partition of cattle in the tropics. British Journal of Nutrition, 81, 227-234. http://dx.doi.org/10.1017/S0007114599000422

Mertens, D. R. (1997). Creating a system for meeting the fiber requirements of dairy cows. Journal of Dairy Science, 80(7), 1463-1481. http://dx.doi.org/10.3168/jds.S0022-0302(97)76075-2

Morrison, M., \& Mackie, R. I. (1996). Nitrogen metabolism by ruminal microorganism: current understanding and future perspective. Australian Journal of Agricultural Research, 47(2), 227-246. http://dx.doi.org.sci-hub.org/10.1071/AR9960227

NRC (National Research Council). (1996). Nutrient requirements of beef cattle (7th ed.). Washington, D.C.: National Academy Press.

NRC (National Research Council). (2001). Nutrients requirements of dairy cattle (7th ed.). Washington, D.C.: National Academy Press.

Olson, K. C., Banner, R. E., \& Wiedmeier, R. D. (2000). Reducing methane emission from beef cow herds in range-based management systems. Final report to the ruminant livestock efficiency program atmospheric pollution prevention division United States Environmental Protection Agency (p. 31). Utah State University: Logan, USA

Orskov, E. R. (1982). Protein nutrition in ruminants. London, UK: Academic Press.

Owens, F. N., \& Zinn, R. (1988). Metabolismo de la proteína en los rumiantes. In D. C. Church (Ed.), El rumiante: Fisiología digestiva y nutrición (3rd ed., pp. 255-281). Acribia: Zaragoza.

Pedreira, M. S. (2004). Estimativa da produção de metano de origem ruminal por bovinos tendo como base a utilização de alimentos volumosos: Utilização da metodologia do gás traçador hexafluoreto de enxofre (SF6) (Unpublished doctoral dissertation, Universidade Estadual Paulista, Brasil).

Possenti, R. A., Franzolin, R., Schammas, E. A., Demarchi, J. J., Frighetto, R. T. S., \& Lima, M. A. (2008). Efeitos de dietas contendo Leucaena leucocephala e Saccharomyces cerevisiae sobre a fermentação ruminal e a emissão de gás metano em bovinos. Revista Brasileira de Zootecnia, 37, 1509-1516. 
http://dx.doi.org/10.1590/S1516-35982008000800025

Preston, T. R., \& Leng, R. A. (1987). Matching ruminant production systems with available resource in the tropics and subtropics. Penambul Books Ltd: Armidale NSW, Australia.

Primavesi, O., Frighetto, R. T. S., Pedreira, M. S., Lima, M. A., Berchielli, T. T., Demarchi, J. J., ... Westberg, H. H. (2004). Técnica do gás traçador SF6 para medição no campo do metano ruminal em bovinos: Adaptações para o Brasil (Documento, 39). Embrapa Pecuária Sudeste: São Carlos, Brasil.

Queiroz, M. F. S., Berchielli, T. T., Morais, J. A. S., Messana, J. D., Malheiros, E. B., \& Ruggieri, A. C. (2011). Digestibilidade e parâmetros ruminais de bovinos consumindo Brachiaria brizantha cv. Marandu. Archivos de Zootecnia, 60, 997-1008. http://dx.doi.org/10.4321/S0004-05922011000400016

Russell, J. B., O’Connor, J. D., Fox, D. G., Van Soest, P. J., \& Sniffen, C. J. (1992). A net carbohydrate and protein system for evaluating cattle diets: I. Ruminal fermentation. Journal of Animal Science, 70, 3551-3561. http://dx.doi.org//1992.70113551x

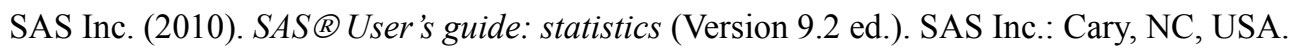

Satter, L. D., \& Rofler, R. E. (1979). Nitrogen requirement and utilization in dairy cattle. Journal of Dairy Science, 58, 1212-1237. http://dx.doi.org/10.3168/jds.S0022-0302(75)84698-4

Satter, L. D., \& Slyter, L. L. (1974). Effect of ammonia concentration on rumen microbial protein production in vitro. British Journal of Nutrition, 32, 199-208. http://dx.doi.org/10.1079/BJN19740073

Slyter, L. L., Satter, L. D., \& Dinius, D. A. (1979). Effect of ruminal concentration on nitrogen utilization by steers. Journal of Animal Science, 48, 906-912. http://dx.doi.org/10.2134/jas1979.484906x

Sniffen, C. J., O’Connor, J. D., Van Soest, P. J., Fox, D. G., \& Russel, J. B. (1992). A net carbohydrate and protein system for evaluating cattle diets: II. Carbohydrate and protein availability. Journal of Animal Science, 70, 3562-3577. http://dx.doi.org//1992.70113562x

Sundstol, F. (1981). Methods for treatment of low quality roughages. In J. A. Kategile, A. N. Sand, \& F. Sundstol (Eds.), Utilization of low-quality roughages in Africa (pp. 61-80). Agricultural University of Norway: Norway.

Thivierge, M. C., Bernier, J. F., \& Lapierre, H. (2002). Effects of supplemental protein and energy and feeding frequency on the performance of lactating dairy cows fed a protein-deficient diet. Canadian Journal of Animal Science, 82, 225-231. http://dx.doi.org//10.4141/A01-066

USEPA (United States Environmental Protection Agency). (2000). Evaluating Ruminant Livestock Efficiency Projects and Programs. Peer Review Draft (p. 48). USEPA: Washington, D.C.

Valadares, R. F. D., Gonçalves, L. C., Rodriguez, N. M., Sampaio, I. B. M., Valadares Filho, S. C., \& Queiroz, A. C. (1997). Níveis de proteína em dietas de bovinos, 1. Consumo e digestibilidades aparentes totais e parciais. Revista Brasileira de Zootecnia, 26(6), 1252-1258.

Van Soest, P. J. (1994). Nutritional ecology of the ruminant (2nd ed.). Cornell Univ. Press: Ithaca, NY.

Wang, L. A., \& Goonewardene, Z. (2004). The use of MIXED models in the analysis of animal experiments with repeated measures data. Canadian Journal of Animal Science, 84(1), 1-11. http://pubs.aic.ca/doi/pdf/10.4141/A03-123

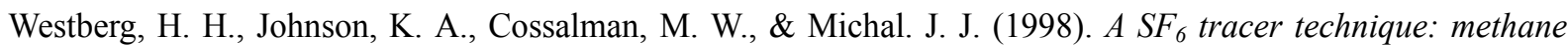
measurement from ruminants (2nd ed.). Washington State University: Pullman-Washington.

\section{Copyrights}

Copyright for this article is retained by the author(s), with first publication rights granted to the journal.

This is an open-access article distributed under the terms and conditions of the Creative Commons Attribution license (http://creativecommons.org/licenses/by/3.0/). 